\title{
MENGOPTIMALKAN PERKEMBANGAN SOSIOEMOSIONAL ANAK USIA DINI MELALUI MEDIA WAYANG
}

\author{
Yona Wahyuningsih
}

\begin{abstract}
ABSTRAK
Kecerdasan emosi merupakan penentu dari keberhasilan seseorang. Sosioemosional pada anak penting dikembangkan karena anak memiliki masa emas perkembangan sosioemosional sesuai tahap perkembangannya. Sejalan dengan kurikulum 2013 yang menitikberatkan pada aspek-aspek perkembangan diri anak salah satunya penekanan pada sosioemosional. Dikembangkannya sosioemosional secara optimal melalui proses pembelajaran dengan menggunakan media berbasis lokal salah satunya yaitu wayang. Penekanan wayang ini bukanlah secara tradional melainkan miniatur yang diaplikasikan seperti pewayangan agar melatih pengendalian diri siswa, mengajarkan pengenalan emosi pada anak, melatih pengelolaan emosi anak, penerapan disiplin dengan konsep empati, mengungkapkan emosi dengan kata-kata, melakukan permainan yang dapat melatih sosial dan emosional anak, dan menanggapi perasaan anak. Hal ini merupakan keterampilan sosial yang harus dikembangkan anak sejak dini. Pembelajaran sejak dini tidak hanya memperkenalkan teknologi canggih namun pemberdayaan budaya pada lingkungan anak pun penting khususnya dalam pembelajaran yang dirancang guru agar ada penanaman kesadaran bahwa anak adalah penerus, pencipta dan investasi masa depan yang perlu dipersiapkan secara optimal.

Kata Kunci: Kecerdasan Sosioemosional, Media Wayang, Anak Usia Dini
\end{abstract}

\section{A. PENDAHULUAN}

Pelaksanaan pembelajaran yang efektif menekankan adanya upaya penyelenggaraan yang mengoptimalkan segala bentuk unsur pendidikan. Cakupan unsur pendidikan meliputi pendidik, peserta didik, kurikulum, pendekatan, model, metode, strategi, dan media yang kreatif dan inovatif. Proses belajar mengajar, unsur-unsur tersebut sangatlah penting dikarenakan pengoptimalan tujuan pembelajaran harus tercapai. Penulis dalam artikel ini menindaklanjuti peran media terhadap pembelajaran.

Belajar pada hakikatnya adalah aktivitas untuk melakukan perubahan tingkah laku pada diri individu yang belajar. Perubahan tingkah laku terjadi karena usaha individu yang bersangkutan baik mencakup ranah-ranah efektif, kognitif dan psikomotor. Pendidikan anak usia dini merupakan salah satu bentuk penyelenggaraan pendidikan yang menitikberatkan pada peletakan dasar ke arah pertumbuhan dan perkembangan fisik (koordinasi motorik halus dan kasar), kecerdasan (daya pikir, daya cipta, kecerdasan emosi, kecerdasan spiritual), sosio emosional (sikap dan perilaku serta agama) bahasa dan komunikasi, sesuai dengan keunikan dan tahap-tahap perkembangan yang dilalui oleh anak usia dini.

Mahasiswa Prodi Pendidikan Dasar SPS UPI 
Pembelajaran masa awal kanak-kanak sering disebut sebagai tahap mainan, karena dalam periode ini hampir semua pembelajaran menggunakan mainan (Hurlock, 2012: 121). Banyak upaya yang dilakukan guru dalam merancang dan mengoptimalkan pembelajaran seperti penyediaan media pembelajaran yang menyenangkan dan menarik bagi anak. Sependapat dengan Dananjaya (2011, 35-36) mengatakan media yang disediakan oleh guru agar murid melakukan aktivitas interaktif yang menyenangkan dan menantang potensi siswa serta membebaskan tumbuhnya prakarsa dan kreativitas murid menjadi manusia yang memiliki kekuatan spiritual keagamaan, pengendalian diri, kepribadian, akhlak mulia dan keterampilan. Jadi dapat dikatakan, media pembelajaran adalah segala sesuatu yang dapat digunakan untuk menyalurkan pesan dari pengirim kepada penerima seperti pendidik maupun peserta didik ataupun lingkungan belajar.

Sebelum membahas lebih lanjut, penulisan artikel ini menyediakan berbagai ulasan perkembangan sosioemosional yang sangat penting sejak dini karena masa perkembangan anak harus dilakukan secara optimal dengan menggunakan media yang menyenagkan seperti wayang. Penekanan wayang disini bukanlah bentuk tradisional melainkan miniature yang diaplikasikan seperti pewayangan. Penggunaan media kertas berupa bentuk orang atau hewan, penggunaan tongkat bergambar. Hal ini diharapkan anak mengetahui dan menanamkan berbagai keterampilan sosioemosional. Tetapi kenyataannya, sebagian besar orang tua dan guru tidak memahami akan potensi luar biasa yang dimiliki anak-anak pada usia itu. Keterbatasan pengetahuan dan informasi yang dimiliki orang tua dan guru, menyebabkan potensi yang dimiliki anak tidak berkembang. Jadi diperlukan pembaharuan yang kreatif dan inovatif berupa penggunaan media.

Tulisan ini mencoba memberikan gambaran tentang optimalisasi perkembangan anak usia dini melalui penggunaan media wayang. Pembahasan yang disajikan meliputi dua topik yaitu perkembangan sosioemosional anak usia dini, penggunaan media wayang terhadap perkembangan sosioemosional anak.

\section{B. PERKEMBANGAN SOSIOEMOSIONAL MELALUI MEDIA WAYANG}

Sebagaimana yang telah dikemukakan pada bagian pendahuluan mengenai fenomena terhadap pembelajaran saat ini bukan hanya terdapat pada permasalahan aspek pendidik ataupun peserta didik melainkan penggunaan media yang kurang membangun pembelajaran bermakna khususnya peningkatan sosioemosional anak sejak dini. Perkembangan sosioemosional anak usia dini dalam tulisan ini yaitu perkembangan masa kanak-kanak awal. Yusuf (Hamdani, 2007) menyatakan bahwa perkembangan sosial merupakan pencapaian kematangan dalam hubungan sosial. Perkembangan sosial dapat pula diartikan sebagai proses belajar untuk menyesuaikan diri terhadap norma-norma kelompok, moral dan tradisi, meleburkan diri menjadi satu kesatuan dan saling berkomunikasi dan kerja sama, sedangkan emosi yaitu perasaan intens yang ditujukan kepada seseorang atau sesuatu. Emosi adalah reaksi terhadap seseorang atau kejadian. Emosi dapat ditunjukkan kerika merasa senang mengenai sesuatu, marah kepada seseorang, ataupun takut terhadap sesuatu. 
Pola perilaku sosial yang terlihat pada masa kanak-kanak awal, seperti yang diungkap oleh Hurlock (1998:252) yaitu: kerjasama, persaingan, kemurahan hati, hasrat akan penerimaan sosial, simpati, empat, ketergantungan, sikap ramah, sikap tidak mementingkan diri sendiri, meniru, perilaku kelekatan. Sedangkan pendapat lain seperti Ericson dalam Papalia, (2008:370) seorang ahli psikoanalisis mengidentifikasi perkembangan sosial anak: (1) Tahap 1: Basic Trust vs Mistrust (percaya vs curiga), usia 0-2 tahun.Dalam tahap ini bila dalam merespon rangsangan, anak mendapat pengalaman yang menyenamgkan akan tumbuh rasa percaya diri, sebaliknya pengalaman yang kurang menyenangkan akan menimbulkan rasa curiga; (2) Tahap 2 : Autonomy vs Shame \& Doubt (mandiri vs ragu), usia 2-3 tahun. Anak sudah mampu menguasai kegiatan meregang atau melemaskan seluruh otot-otot tubuhnya. Anak pada masa ini bila sudah merasa mampu menguasai anggota tubuhnya dapat meimbulkan rasa otonomi, sebaliknya bila lingkungan tidak memberi kepercayaan atau terlalu banyak bertindak untuk anak akan menimbulkan rasa malu dan ragu-ragu; (3) Tahap 3 : Initiative vs Guilt (berinisiatif vs bersalah), usia 4-5 tahun. Pada masa ini anak dapat menunjukkan sikap mulai lepas dari ikatan orang tua, anak dapat bergerak bebas dan ber interaksi dengan lingkungannya. Kondisi lepas dari orang tua menimbulkan rasa untuk berinisiatif, sebaliknya dapat menimbulkan rasa bersalah; (4) Tahap 4 : industry vs inferiority (percaya diri vs rasa rendah diri), usia 6 tahun - pubertas.

Anak telah dapat melaksanakan tugas-tugas perkembangan untuk menyiapkan diri memasuki masa selanjutnya sehingga perlu memiliki suatu keterampilan tertentu. Bila anak mampu menguasai suatu keterampilan tertentu dapat menimbulkan rasa berhasil, sebaliknya bila tidak menguasai, menimbulkan rasa rendah diri. Berkaitan dengan hal tersebut dipaparkan mengenai peranan dan fungsi dari perkembangan sosioemosional anak usia dini (Rizal, 2013) sebagai berikut.

1. Bentuk komunikasi sehingga anak dapat menyatakan segala kebutuhan dan perasaannya pada orang lain. Sebagai contoh, anak yang merasakan sakit atau marah biasanya merupakan mengekspresikan emosinya dengan menangis. Menangis ini merupakan bentuk komunikasi anak dengan lingkungannya pada saat ia belum mampu mengutarakan perasaannya dalam bentuk bahasa verbal. Demikian pula halnya ekspresi tertawa terbahak-bahak ataupun memeluk ibunya dengan erat. Ini merupakan contoh bentuk komunikasi anak yang bermuatan emosional.

2. Emosi berperan dalam mempengaruhi kepribadian dan penyesuaian diri anak dengan lingkungan sosialnya, antara lain berikut ini.

a. Tingkah laku emosi anak yang ditampilkan merupakan sumber penilaian lingkungan sosial terhadap dirinya. Penilaian lingkungan sosial ini akan menjadi dasar individu dalam menilai dirinya sendiri. Penilaian ini akan menentukan cara lingkungan sosial memperlakukan seorang anak, sekaligus membentuk konsep diri anak berdasarkan perlakuan tersebut. Sebagai contoh, seorang anak sering mengekspresikan ketidaknyamanannya dengan menangis, lingkungan sosialnya akan menilai ia sebagai anak yang "cengeng”. Anak akan diperlakukan sesuai dengan penilaiannya tersebut, misalnya entah sering 
mengolok-olok anak, mengucilkannya atau bisa juga menjadi over protective. Penilaian dan perlakuan terhadap anak yang disebut "cengeng" ini akan mempengaruhi kepribadian dan penilaian diri anak.

b. Emosi menyenangkan atau tidak menyenangkan dapat mempengaruhi interaksi sosial anak melalui reaksi-reaksi yang ditampilkan lingkungannya. Melalui reaksi lingkungan sosial, anak dapat belajar untuk membentuk tingkah laku emosi yang dapat diterima lingkungannya. Jika anak melempar mainannya saat marah, reaksi yang muncul dari lingkungannya adalah kurang menyukai atau menolaknya. Reaksi yang kurang menyenangkan ini, membuat anak memperbaiki ekspresi emosinya agar dapat diterima di lingkungan masyarakatnya. Demikian pula halnya dengan ekspresi emosi yang disukai lingkungannya. Anak yang empati dan suka berbagi mainan dengan temannya, akan disukai oleh lingkungannya. Anak akan tetap mempertahankan perilakunya karena ia menyukai reaksi lingkungan terhadapnya.

c. Emosi dapat mempengaruhi iklim psikologis lingkungan. Tingkah laku emosi anak yang ditampilkan dapat menentukan iklim psikologis lingkungan. Artinya, apabila ada seorang anak yang pemarah dalam suatu kelompok maka dapat mempengaruhi kondisi psikologis lingkungannya saat itu, misalnya permainan menjadi tidak menyenangkan, timbul pertengkaran atau malah bubar.

d. Tingkah laku yang sama dan ditampilkan secara berulang dapat menjadi satu kebiasaan. Artinya, apabila seorang anak yang ramah dan suka menolong merasa senang dengan perilakunya tersebut dan lingkungan pun menyukainya maka anak akan melakukan perbuatan tersebut berulang-ulang hingga akhirnya menjadi kebiasaan.

e. Ketegangan emosi yang dimiliki anak dapat menghambat atau mengganggu aktivitas motorik dan mental anak. Seorang anak yang mengalami stress atau ketakutan menghadapi suatu situasi, dapat menghambat anak tersebut untuk melakukan aktivitas. Misalnya, seorang anak akan menolak bermain finger painting (melukis dengan jari tangan) karena takut akan mengotori bajunya dan dimarahi orang tuanya. Aktivitas finger painting ini sangat baik untuk melatih motorik halus dan indra perabaannya. Namun, hambatan emosional (takut dimarahi orang tuanya) anak menjadi kehilangan keberanian untuk mencobanya dan hilanglah kesempatan pengembangan dirinya.

Sependapat pula dengan Hurlock (1978) mengatakan fungsi dan peranan kemampuan social pada perkembangan anak adalah sebagai berikut (1) Belajar untuk bertingkah laku dengan cara yang dapat diterima masyarakat, (2) Belajar memainkan peran sosial yang ada dimasyarakat. (3) Mengembangkan sikap/ tingkah laku sosial terhadap individu lain dan aktivitas sosial yang ada di masyarakat.

Hal-hal diatas sangatlah ideal dan efektif dalam perkembangan sosioemosional anak, segala upaya dilakukan guru agar perkembangan yang dialami oleh siswa dapat optimal berbagai carapun dilakukan seperti pengelolaan pembelajaran agar menyenangkan dan menarik yang dirasakan siswa tanpa ada 
jenuh, paksaan. Salah satu upaya yang dilakukan dengan penggunaan media berbasis local yaitu wayang yang penekanannya pada miniatur yang diaplikasikan seperti pewayangan yaitu dengan menggunakan kertas ataupun stik bergambar. Tahap perkembangan anak usia dini adalah masa bermain maka upaya media tersebut dapat dimanfaatkan dan dikelola sedemikian rupa untuk penekanan sosioemosional anak. Pementasan wayang ini menjadikan bahan untuk menanamkan keterampilan diri anak berupa pengendalian diri siswa, mengajarkan pengenalan emosi pada anak, melatih pengelolaan emosi anak, penerapan disiplin dengan konsep empati, mengungkapkan emosi dengan kata-kata, melakukan permainan yang dapat melatih sosial dan emosional anak, dan menanggapi perasaan anak. Hal ini sependapat dengan Papalia (2009: 400) mengatakan bahwa salah satu bentuk permainan yang menjadi lebih sosial selama masa prasekolah adalah permainan imajinatif yang sering kali beralih dari pura-pura sendiri menjadi permainan drama yang melibatkan anak lain. Ketika permainan imajinatif lebih kolaboratif, jalan cerita lebih menjadi kompleks dan inovatif. Permainan dramatis memberikan banyak kesempatan untuk melatih keterampilan antarpribadi serta mengeksplorasi berbagai peran. Dengan berpura-pura, anak melakukan coping terhadap emosi yang tidak nyaman, memperoleh pemahaman mengenai sudut pandang orang lain, dan membangun citra dunia sosial.

Media wayang merupakan media pembelajaran dilakukan melalui kegiatan bercerita. Perlu diketahui bahwa wayang disini bukan dalam arti fisik (baca: wayang kulit), melainkan dalam bentuk miniature yang diaplikasikan seperti pewayangan berupa stik bergambar. Guru cukup menceritakan kisah atau cerita yang mengandung nilai kebaikan serta mengajarkan karakter tokoh wayang tersebut untuk diteladani oleh siswa. Misalnya kisah tentang binatang, orang, tumbuhan ataupun objek lainnya, yang memiliki sifat dan karakter dari setiap onjek wayang seperti antagonis, protagonis dengan berbagai ekspresi. melalui peratara cerita siswa belajar berbagai karakter wayang yang pantas hingga yang kurang pantas diteladani sekaligus memupuk pengetahuan.

Wardani (2011) mengatakan beberapa kelebihan yang dimiliki oleh wayang sebagai media pendidikan karakter. Pertama, wayang bersifat acceptable. Artinya, wayang sendiri merupakan bagian dari khasanah kebudayaan bangsa sehingga bisa diterima oleh semua kalangan, baik oleh guru maupun siswa. Kedua, wayang bersifat timeless yang berarti tak lekang oleh waktu. Adanya sifat ini membuat wayang sebagai media pembelajaran karakter dapat digunakan secara turun temurun pada generasi pelajar selanjutnya. Ketiga, media wayang ini tidak membutuhkan banyak biaya seperti media lain serta praktis dan efisien. Bercerita tentang wayang tidak membutuhkan fasilitas penunjang dalam bentuk apapun melaikan yang dibutuhkan hanyalah kemampuan guru dalam mengekpresikan cerita tersebut dalam kalimat yang jelas dan menarik agar mudah dimengerti oleh siswa.

Sekarang pendidikan karakter mulai digalakkan di sekolah-sekolah salah satu aspek karakter adalah penekanan soioemosional anak yang dilakukan sejak dini. Pendidikan yang sekarang dinilai gagal menciptakan manusia yang berkarakter karena terlalu fokus terhadap peningkatan pengetahuan dan terlalu menonjolkan 
kecerdasan berpikir. Penekanan sosioemosinal yang menjadi kunci upaya perbaiakan dan pembaharuan dalam peningkatan mutu pendidikan. Pencanangan Nation and charakter building atau yang lebih dikenal dengan pendidikan karakter merupakan jembatan perwujudan dari pendidikan.

\section{PENUTUPAN}

Pembelajaran yang bermakna dapat dilihat dengan upaya pengelolaan yang dilakukan guru sedemikian rupa agar menarik dan menyenangkan yang dirasakan siswa. Tidak hanya penggunaan teknologi canggih namun pemberdayaan budaya dalam bentuk lainnya pun mampu menjadi media pembelajaran seperti media wayang yang penekanannya terhadap miniatur yang diaplikasikan seperti pewayangan dengan pengharapan penanaman nilai kebaikan serta mengajarkan karakter tokoh wayang tersebut untuk diteladani oleh siswa serta keterampilam perkembangan emosional seperti melatih pengendalian diri siswa, mengajarkan pengenalan emosi pada anak, melatih pengelolaan emosi anak, penerapan disiplin dengan konsep empati, mengungkapkan emosi dengan kata-kata, melakukan permainan yang dapat melatih sosial dan emosional anak, dan menanggapi perasaan anak.

\section{DAFTAR PUSTAKA}

Dananjaya, U. 2011. Media Pembelajaran Aktif. Bandung: Penerbit Nuansa Cendekia.

Hurlock, E B. 2012. Psikologi Perkembangan Suatu Pendekatan Sepanjang Rentang Kehidupan. Jakarta: Erlangga.

Hurlock, E.B. (1978). Chiled Development. 6th Ed. Tokyo : Mc. Graw Hill. Inc., International Studend $\mathrm{Ed}$.

Papalia, Olds, Feldmen. 2009. Human Development. Jakarta: Salemba Humanika

Wardani. 2011. Wayang Media Pendidikan Karakter Bangsa . [online]. Tersedia: http:// edukasi.kompasiana.com/2011/12/16/wayang-media-pendidikkarakter-bangsa-422608.html

http://id.wikipedia.org/wiki/Emosi

http://h4md4ni.wordpress.com/perkembang-anak/ 